Dialectologia 25 (2020), 25-43.

ISSN: 2013-2247

Received 21 September 2018.

Accepted 21 November 2018.

\title{
DESIGNING A LINGUISTIC PROFILE OF KHORTHA: A LESS RESOURCED LANGUAGE SPOKEN IN THE STATE OF JHARKHAND, INDIA
}

\author{
Atul AMAN ${ }^{1}$, Niladri Sekhar DASH ${ }^{1}$ \& Jayashree CHAKRABORTY ${ }^{2}$ \\ Linguistic Research Unit, Indian Statistical Institute, Kolkata ${ }^{1 *}$ \\ Dept. of HSS, Indian Institute of Technology, Kharagpur ${ }^{2}$ * \\ atul.aman1@gmail.com /ns_dash@yahoo.com / shree@hss.iitkgp.ernet.in
}

\begin{abstract}
This paper describes the linguistic outline of Khortha language, which is spoken in the state of Jharkhand, India. Khortha is the second most spoken language after Hindi in the state of Jharkhand, with approximately 80 million speakers (As per the Govt. of India, census reports 2011). The paucity of the language resources in Khortha played a vital role in motivating us for the present work. The methodology adopted for the present study comprises linguistic field surveys (Dash \& Aman 2015) and reviews on the earlier literature of Khortha. The current status and demographic profile of Khortha suggest its usage as a link language among the other indigenous language communities (i.e. Munda, Bedia, Kurmali, etc.) as well. The scope (usage) of the Khortha language within the various domains (i.e. administration, education, mass media, social divisions and religion, judiciary and interpersonal communication), as discussed in the paper, gives a clear idea of its usage and linguistic identity. This paper can be a helpful resource for the researchers in order to portray the current linguistic status of the language.
\end{abstract}

\section{Keywords}

Khortha, language resources, earlier literature, demographic profile, linguistic identity

\footnotetext{
* Linguistic Research Unit, Indian Statistical Institute, 203, B.T Road, Kolkata, 700108, West Bengal, India.

* Department of Humanities and Social Sciences, Indian Institute of Technology, Kharagpur, 721302 West Bengal, India.
} 


\section{DISEÑANDO UN PERFIL LINGÜÍSTICO DEL KHORTHA: UN IDIOMA CON POCOS RECURSOS HABLADO EN EL ESTADO DE JHARKHAND, INDIA}

\section{Resumen}

Este artículo lleva a cabo un esbozo lingüístico de la lengua khortha, que se habla en el estado de Jharkhand, India. El khortha es el segundo idioma más hablado después del hindi en el estado de Jharkhand, con aproximadamente 80 millones de hablantes (según el Gobierno de India, informes del censo de 2011). La escasez de recursos lingüísticos en Khortha jugó un papel vital para motivar el presente trabajo. La metodología que se ha adoptado comprende encuestas lingüísticas (Dash \& Aman 2015) y reseñas sobre la literatura anterior del khortha. El estado actual y el perfil demográfico del khortha sugieren que se usa también como una lengua de enlace entre las otras comunidades de lenguas indígenas (es decir, el munda, el bedia, el kurmali, etc.). El alcance (uso) del idioma khortha dentro de los diversos dominios (es decir, la administración, la educación, los medios de comunicación, las divisiones sociales y la religión, el poder judicial y la comunicación interpersonal), como se expone en el artículo, da una idea clara de su uso e identidad lingüística. Este trabajo puede ser un recurso útil para los investigadores a fin de retratar el estado lingüístico actual de la lengua.

\section{Palabras clave}

Khortha, recursos lingüísticos, literature antiga, perfil demográfico, identidad lingüistica

\section{Introduction}

Khortha is officially recognized as the second most spoken language of the state (Hindi being the first one) with a total number of 4725927 speakers using Khortha as their first language or the mother tongue (Census 2001). The Census 2011, reports approximately 80 million Khortha speakers. According to some researchers (Prasad \& Shastri 1958: 9), Khortha is identified as a variety of Maithili, while others consider it as a sub-variety of Hindi (Census 2001, 2011). The name 'Khortha' itself refers to a corrupt or impure form of a language (Prasad \& Shastri 1958: 9). According to Ohdar (2012), as many as fifteen districts in the state of Jharkhand (i.e., Gadhwa, Palamu, Latehar, Chatra, Hazaribagh, Ramgarh, Bokaro, Dhanbad, Koderma, Giridih, Deoghar, 
Dumka, Godda, Pakud, and Sahebganj) are densely populated by native Khortha speakers.

\section{Etymological Significance of Khortha}

The evolution of the word 'Khortha' carries a significant etymological importance. The most common meanings of the word Khortha, as stated in Ohdar (2012), are regional, vernacular, rural and so on. One of the researchers, A.K. Jha (as cited by Ohdar) opines that the word Khortha has evolved from the ancient script Kharosthi, and from Kharosthi, as a result of some phonological changes, the present term Khortha is generated. The two different streams of these phonological changes as stated by $A \mathrm{~K}$ Jha are given in the following figure.
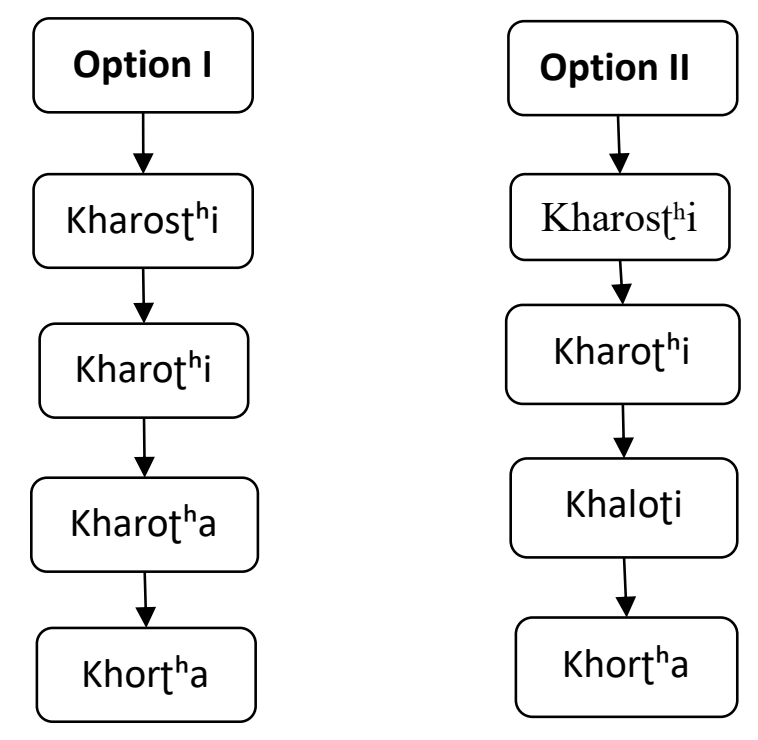

Figure 1. Evolution chart of the Kharosthi into 'Khortha'

Another important claim about the etymology of the word Khortha is made by Krishna Chandra Das 'Ala' in his work Khortha Bhasha Grahane (cited by Ohdar 2012) where it is pointed out that the word Khortha has not evolved from Kharosthi, rather 
it has evolved from Khartha which means 'nature' in Khortha. As the two words Khartha and Khortha sound more identical than Kharosthi and Khortha, Das has taken on this option. However, the majorities of experts agree with the claim made by Jha and relate Khortha to Kharosthi.

\section{Status of Khortha Language}

The indigenous speech community of Jharkhand, specifically the Santhali community, has often been linked with this language. This can justify Khortha being a lingua franca (link) within the state. During our data collection, it was observed that people from other indigenous language communities, namely Munda, Bedia and Kurmali also prefer to use Khortha as their first language. The same phenomenon (the tendency of using Khortha as the first language by the indigenous people of Jharkhand) is also reported by earlier researchers (Dangi 2012, Ohdar 2012).

According to Ohdar (2012), there has been a trend of using Khortha as the first language by the indigenous people of the state, though the other indigenous languages like Santhali, Bedia and Kurmali also existed in the neighbouring areas at the same time. At some point of time perhaps the area was inhabited by several smaller indigenous groups. It is possible that at some point in history, the smaller groups of indigenous speakers felt the urge of using a common language across communities. Khortha was the answer to resolve this communication crisis of a link language. The infrequent use of the other languages might have led the speakers of indigenous communities to forget their mother tongue and adopt the new language (read Khortha) as their preferred (first) language (Ohdar 2012).

It is worth mentioning that earlier literary works on Khortha (Dangi 2012, Ohdar 2012, Prasad \& Shastri 1958) reported the presence of at least five different varieties of the language. While we sincerely acknowledge the effort and contributions of these researchers on the language, we would like to mention that most of these works lack 
a proper (linguistic) documentation methodology. ${ }^{1}$ These gaps surely necessitate further attention in documenting the language scientifically. One of the major goals of this study is to meet this purpose.

During our multiple rounds of field trips, we felt that the current scenario of Khortha as a language is under serious crisis. This language has been gradually losing its speakers over the years. Among numerous reasons behind this downfall, a few can be mentioned here. The impact of other well-accepted dominant languages of the state has a role in this direction. The poor economic condition of the native people forced them to migrate to other parts of India in search of occupation, food, shelter and a better life. Due to migration, the younger generation is on the verge of losing their mother tongue permanently. It is noticed that the native Khortha speakers are keen to be associated with standard and superior language(s) like Hindi, Urdu, and perhaps English too. The circumstances are such that, in many situations, the native speakers are somehow forced to learn and use Hindi.

In a multilingual country like India, it is impossible for the (local) government to provide (primary) education in all the vernacular languages of the state. Khortha is not an exception to this. The native Khortha speakers are exposed to major languages such as Hindi and Urdu at an early age as they come in direct contact with these languages at the primary and secondary level of education. Since Hindi and English are the most dominant language ${ }^{2}$ of the state of Jharkhand, the native Khortha speakers are left with no option other than learning and using these languages in all the formal situations, and in many cases, informal situations too. Due to these factors, the native speakers appear to be little hesitant to use their mother tongue in a multilingual environment. The younger generation hardly gets any space to use their mother tongue except in those informal situations where all the interlocutors do not have other options.

It is worth mentioning that Khortha has a very rich linguistic tradition comprising a huge collection of folklore, folk-songs, folktales, riddles, lullabies, marriage songs, birth

\footnotetext{
${ }^{1}$ Most of the literature available on Khortha acknowledges the contribution of A. K. Jha. Jha's endeavor has definitely raised the status of Khortha. A few of his major works include Khortha Sahit Sadanik Vyakaran, Chhand Ras Alankar and Khortha Bhasha Vigyan to name a few. Unfortunately, most of these works lack proper publication details.

${ }^{2}$ These are the dominant languages of India too.
} 
songs, elegies, etc. These collectively characterize a rich lexical stock and linguistic materials of the language. It is also to be noted that even the website Ethnologue does not contain any linguistic or non-linguistic information of Khortha except that Khortha is referred to as one of the varieties of Angika which is spoken in the western part of Jharkhand and Bihar (Das 2013).

\section{The Demographic Profile of Khortha}

There is an interesting observation regarding the use of the Khortha in the state of Jharkhand. Dangi (2012: 19) claimed that the language is spoken in fifteen districts of Jharkhand which are on the northern side of the Tropic of Cancer. It runs nearly through the middle of the state in north-south dimension (approximately 23 $58^{\prime} 10^{\prime \prime}$ North longitude to $25^{\circ} 19^{\prime} 15^{\prime \prime}$ North latitude and $83^{\circ} 20^{\prime} 50^{\prime \prime}$ to $88^{\circ} 4^{\prime} 40^{\prime \prime}$ at East latitude). It is claimed that the language is not in use on the southern side of this geographical line. However, it is difficult to explain how a language has been in recurrent use on one side of the Tropic of Cancer and not on the other side, even though the state is stretched on both sides of the line.

Our observations, however, reveal that there are places in the southern side of this line where the language is well in use, although not as frequently as it could be observed in the northern districts of the state. It can be suggested that there might be some sociocultural, historical as well as ethnic-cum-anthropological factors behind the clustering of the indigenous people and other communities of state promoting the practice of Khortha as the first language in those regions (Figure 2). 


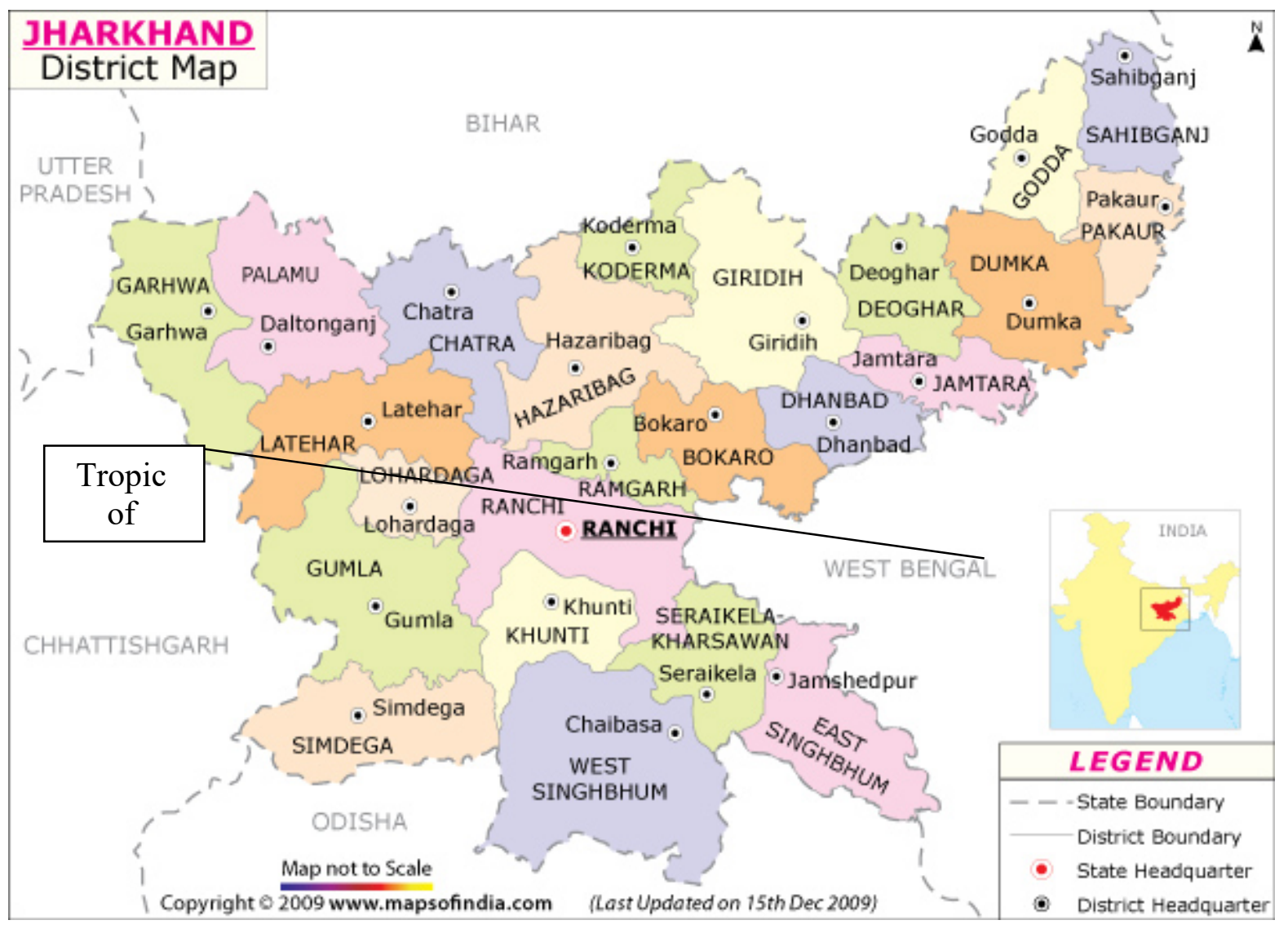

Figure 2. Geographical description of Khortha in Jharkhand state

\section{Languages of Jharkhand and their origin}

Like many other states in India, the state of Jharkhand can also be categorized as a multi-ethnic, multi-cultural and multi-lingual state. Numerous languages, representing at least three different language families, viz., Austro-Asiatic, Dravidian, and Indo-Aryan are well in practice in the state. Geographically, Jharkhand was a part of the state of Bihar, which possesses a different linguistic identity altogether (Ohdar 2012).

The languages representing the Austro-Asiatic language family includes Santhali, Mundari, Munda, Ho, and Kharia. Languages such as Kurukh/Oraon, Malto, Korwa, Telugu, Tamil, Malayalam, and Kannada form the Dravidian language group. The representative languages of the Indo-Aryan family are Hindi, Khortha, Bangla, Urdu, Nagpuri, Kurmali, Panchparganiya, Odia, Maithili, Punjabi, Gujarati, Magahi, Bhojpuri and 
Sadri. The language families are described by the following diagrammatic tree representation (Fig. 3).

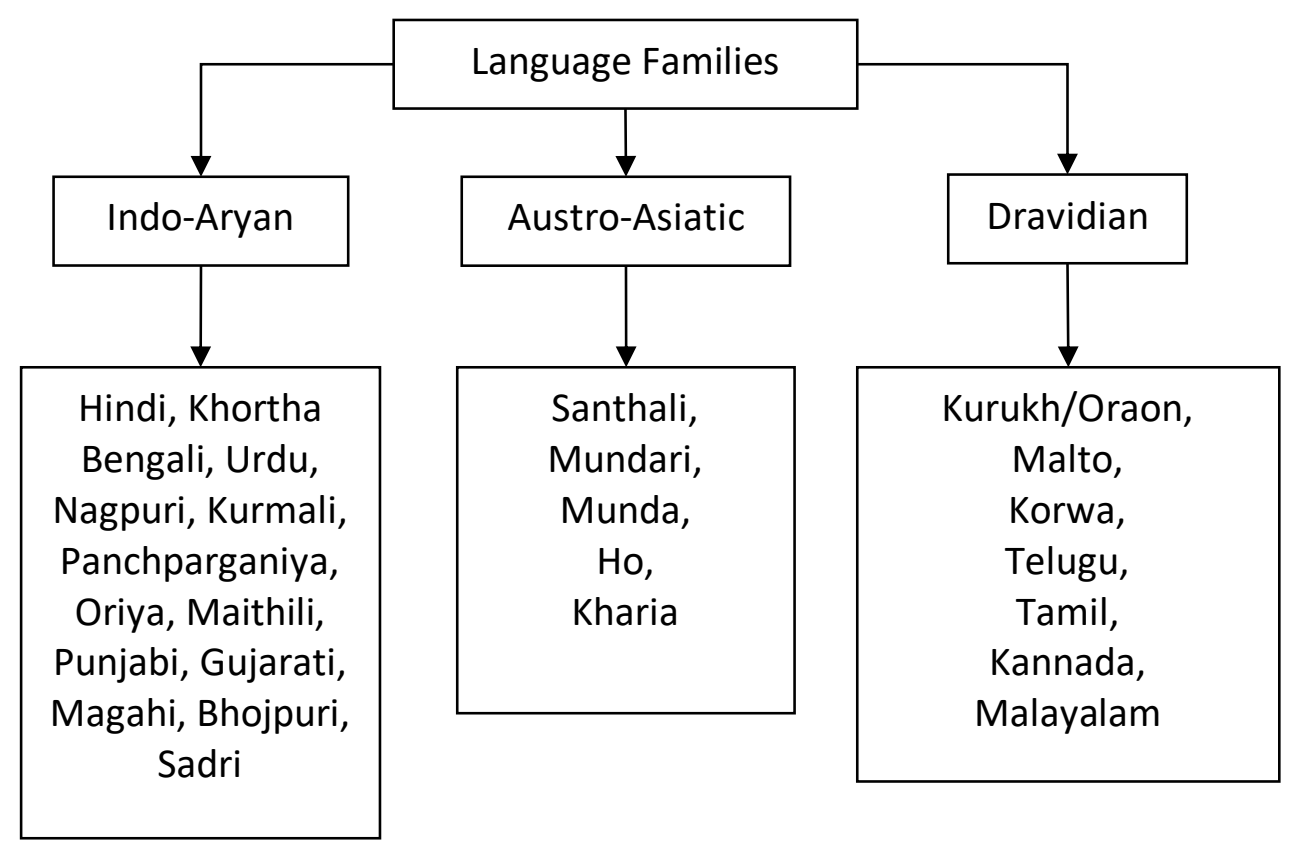

Figure 3. Languages under different language families in Jharkhand, India

\section{Earlier studies on Khortha}

Despite being the second most widely spoken language of the state, Khortha lacks proper documentation and recognition. Only a few literary works are available in the form of local narratives, poetry, and proverbs. Attempts were taken in the past to describe the grammatical structures of the language; however, none of these works seems to follow a proper linguistic documentation procedure. Unfortunately, the majority of the earlier works are not available in printed form or any other form of recognized and easily accessible electronic media.

Notwithstanding the fact that Jharkhand forms an integral part of Bihar (before the formation of the separate state), the state of Jharkhand appears to be distinct with respect to the status of Languages and Culture of the state. The locals of Jharkhand, for long, were ill-treated and considered inferior. They did not have good relations and 
friendly communication with others belonging to the same caste. The natives of the state are identified by a separate name 'kol': /kol-kurmi/, /kol-teli/ etc. This segmentation of the native people of Jharkhand has severely affected the growth of the state, despite having an abundance of agriculture and minerals (Ohdar 2012).

The native inhabitants and their basic needs, hard work and labour have always been underestimated. Whenever they have demanded an equal treatment, they have been used awfully by the dominant class for the sake of earning a profit on a larger scale.

Jharkhand, being surrounded by the states of Bihar, West Bengal, Uttar Pradesh, and Chhattisgarh, has also been affected with respect to its language i.e. Khortha. Languages like Bhojpuri, Magahi, Bengali, Odia, Chhattisgarhi, have influenced the Khortha language and their properties can be seen in the various speech varieties of Khortha. By the time George Grierson (1927) started compiling his work with Linguistic Survey of India, it is assumed that the native properties of the languages of Jharkhand were missing. Nagpuri was identified as Bhojpuri but the other languages were not identified. Similarly, in the Linguistic Survey of Sadar Division of Manbhoom and Dhalbhoom, Kurmali, Khortha, Panchparganiya were identified as Eastern Magahi (Prasad \& Shastri 1958).

Shriniwas Panuri in 1950 translated the great poet Kalidasa's Meghadutam in Khortha which created an impact on the native Khortha speakers as well as the other neighbouring languages. Other than this, he started publishing two magazines annually viz. Matribhasha and Titki which were however discontinued later. In 1956, there were two other works Balkiran and Divyajyoti by him which were among the earlier poetic works in Khortha.

It is assumed that the works in Khortha language were initiated before 1950's and many scholars like Bhuwaneshwar Datt Sharma, Shriniwas Panuri, Viswanath Dasoundhi, and Viswanath Nagar were among the first group of people who initially contributed to Khortha literature (Ohdar 2012).

Below we have listed the names of a few scholars, who have contributed to the growth of Khortha literature, along with their important literary works. 
(1) Shriniwas Panuri: His poetic contributions are: [balkirən (1954)], [diuja-dzoti (1954)], [meg ${ }^{\text {h }}$ ut (1969)], [ram kəthamrit (1971)], [malak p pul (1972)], Chabhi-kat ${ }^{\text {hi }}$ [tab ${ }^{h_{i}}-k a t^{h_{i}}$, a drama (2006)].

(2) A.K. Jha: His contribution includes $\left[k^{h}\right.$ ort $^{\text {h } a} k a t^{\text {hẽ }}$ gəidek $k^{\text {hã }}$ ri which contains essay and poetry both (1983)], [ek toki $\mathrm{p}^{\mathrm{h}} \mathrm{ul}$ - a collection of folk songs (1984)], [meka-meki ne metmãt- a drama (1991)], [kəvitapuran- a collection of children's poetry (1995)]

(3) Shivnath Pramanik's poetic contributions are- [rusəl putus (1985)], [damudrek korãe (1987)], [tatəl-hemal; ek kəvita (1998)]

(4) B.N. Ohdar's work Khortha Bhasa Sahitya: udbhav evam vikas (2007 \& 2012)

These native language experts contributed continuously for a long period of time in the form of local narratives, poetry, stories, folktales, lullabies, folksongs, ballads, etc. It is however surprising to note that none of the works went to any national or international forums. The reasons could be many. From a linguistic perspective, it could be due to the non-inclusion of any linguistic methodology as field surveys, analytical research findings based on the experimental results and other methods which are considered reliable sources for establishing language related facts.

A few local magazines, published in Khortha, are given in the following list:
(a) [matrib ${ }^{\mathrm{h}} \mathrm{a}$ a] by Shriniwas Panuri (1957)
(b) $\left[k^{\text {h }}\right.$ ort $^{\text {ha }}$ ] by Shriniwas Panuri (1970)
(c) [titki] by Viswanath Dasaundhi (1977)
(d) [titki] by Shantibharat and Dinesh Dinmani (1997)
(e) [luat ${ }^{h_{i}}$ ] by Akashkhunti (1999)
(f) [kəril] by Dr Paras Nath Mahato (2009)
(g) [indzor] by Dhananjay Prasad (1997) 


\section{Socio-Economic status of the Khortha speakers}

Based on the geographical distribution of the language, the Khortha speech community can broadly be divided into two sub-groups within the state of Jharkhand, i.e. Rural and Urban. During our field trips, we observed that there is a clear distinction among the native speakers based on their economic background. The speakers with poor economic background are labelled as the people belonging to lower caste and they are looked upon with a sense of inferiority. However, these are people who use their mother tongue in all possible fields of communication in their day to day life with full commitment.

On the other hand, the educated and economically stronger group is gradually limiting the use of Khortha in their day to day life. The possible reason behind such shift could be due to their access to the dominant languages such as Hindi and English. The frequent use of these dominant languages provides a psychological boost to uplift the social and professional status among the native speakers. The indigenous speech community thus uses Khortha and Hindi both as their link language for their daily needs.

\section{Scope of the Khortha Language}

For measuring the scope of the language, the various domains in which the language is used by the native speech community are identified as the following

\subsection{Administration}

In the state of Jharkhand, Hindi and English both are recognised as the official languages of the state. However, there has been a talk of providing official language status to nine other regional languages, viz. Santhali, Ho, Kurukh, Mundari, Kharia, Nagpuri, Panchparganiya, Khortha and Kurmali (Telegraph, Kolkata, 2011). The official bill (demand) was also passed by the state assembly in 2011; however, there has been no 
such official announcement as yet. Based on the recorded free speech discourse of the native Khortha speakers and the official employees at different sectors of the state, we came to the conclusion that the majority of native Khortha speakers do follow Hindi and English and outside their own regions and villages they prefer to use either of these languages in conversations. Consequently, the young educated generation, especially the people of higher status, are on the verge of losing their mother tongue. In most of the cases, the educated people no longer wish to be associated with the language of low status. It is only the poor, marginalized and people with little or no education, who carry an emotional attachment to the language.

\subsection{Education}

The state of Jharkhand possesses a much-diversified range of educational institutions ranging from primary to the professional ones spread across different parts of the state. In most of the cases institutions, the medium of instruction is either English or Hindi or both in some cases. There are also a few vocational courses at the school and college level where foreign languages are also taught. Apart from such courses, there is a department of tribal languages in Ranchi University. This department, however, does not include the Khortha language as it is not included in the list of tribal languages of the state. There is no provision for teaching this language even at the primary level of education, and the children are forced to pursue their education in either English or Hindi medium. Hence, the use of Khortha is restricted only to some private or semi-private institutions.

\subsection{Mass media}

Khortha possesses a rich variety of regional songs of different genres recorded locally and distributed widely through social networking domains across the country. The present researcher also watched some Khortha movies and observed that the number of fans of these movies is huge among the native Khortha speakers. Recently, the native Khortha speakers experienced a historic moment when a Khortha movie was projected in 
the Bollywood silver screen named, 'Chauranga'. The movie also won multiple National and International Awards. The biggest surprise for the native speakers came when the movie was projected globally and was watched by a wider mass. Even though the medium of the language was claimed to be Khortha, after watching the movie, one can be claimed that the film was mostly projected in Hindi and only a few lexical items of Khortha were used.

\subsection{Social divisions and Religion}

After the partition of the Southern part of the state of Bihar on $15^{\text {th }}$ November 2000 , the state of Jharkhand started sharing its border with the states of Bihar in the north, Uttar Pradesh and Chhattisgarh in the west, Odisha in the south and West Bengal in the east. During field surveys, we experienced the presence of strong divisions among the native speakers of Khortha based on their economic and educational status. In the urban areas, the use of the Khortha language prevails very less and the usage is confined mostly to the people belonging to the lower-income category. The rich and educated aboriginal Khortha Speakers, on the other hand, feel embarrassed to be associated with this language.

\subsection{Judiciary}

The judiciary system of the Jharkhand state was carved out from the Bihar jurisdiction in the year 2000 and since then it is being run under the Government of India. When it started, the medium of language was Hindi/English which remains unchanged until now. There has been no regulation regarding the inclusion of any other regional and indigenous languages of the state. 


\subsection{Interpersonal communication}

The interpersonal skills within the Khortha speakers were found to be similar to those of the other dominant languages of the respective areas in Jharkhand. It has been noticed that the local residents of the various villages have developed a strong affinity with the language and successfully carry out the various activities with the other members of their community in the various domains such as agriculture, local business and the other common workplaces where a team effort is required. The native speakers are found to be very much agile and competent in using their mother tongue according to the demands of various situations. They display their skills in all communicative acts, verbal and non-verbal namely, listening, negotiation, decision making or being assertive in a particular situation and so on. The native speakers of Khortha seem to be efficient and productive in every domain.

\section{Speech varieties of Khortha}

Following Dr. Jha's work $\left[k^{h}\right.$ ort ${ }^{h} a$ sadani $b^{h} a \int a$ sanskriti ke vibhinna pehluõ par vitfar], Ohdar (2012) acknowledged Jharkhand as a multi-ethnic and a multi-lingual area- an area that hosts a variety of languages including the indigenous languages of the state. The geographical distribution of these languages and the numerous 'language contact' situation further resulted in various varieties of a single language. The native speakers of Khortha have spread across the whole Chotanagpur area, the sadaans (the aboriginal people) of Santhal Paragana where the indigenous community and the Santhal community use this language as a Lingua Franca to communicate among themselves. According to Jha (as cited in Ohdar 2012), Khortha has two major regional varieties

(a) [sik ${ }^{h}$ rija] or $\left[k^{h} a s p a i l i j a\right]$ and

(b) [golvari] 
The areal distribution of these varieties owns an interesting story. Ohdar (2012), following Dr Jha, claimed that the areal distribution of these two varieties of Khortha can be explained on the basis of the size, texture, and speciality of grains, the measuring device of which is known as Grain Measuring Device or '[pəila]'. For the first variety i.e. [sik ${ }^{h}$ rija] or [ $k^{\text {h}}$ aspəilija], the device [pəila] is believed to be capable of holding 14 Chhatank $^{3}$ of grains which is approximately 875 grams. This kind of device is considered to be special because of its special size and texture and hence the device is named as [ $\mathrm{k}^{\mathrm{h}}$ aspəilija] where ' $\mathrm{k}^{h} a s^{\prime}$ means special. The device is made up of brass and aluminium and is designed by the indigenous community [sekra] (The meaning of sekra in many languages is a goldsmith' so probably here in Khortha, it refers to the same). It is possible that the word [sik ${ }^{\text {h}}$ rija] is a coinage from the earlier word [sekra]. The area which comes under this measuring device is named as [sik ${ }^{\mathrm{h}} \partial \mathrm{rija}$ ] or [ $\mathrm{k}^{\mathrm{h}}$ aspəilija]. This area is presently traced from Bokaro district of Jharkhand to the bordering areas of East Bengal. Thus, a lot of Bangla lexical properties can be observed in this variety of Khortha (enlisted as Khortha-2). Consider the following examples

\begin{tabular}{|c|c|c|c|}
\hline SI. no & Khortha 1 & Khortha 2 & Gloss \\
\hline 1 & /eibate/ & /eidige/ & Here \\
\hline 2 & $/ t^{\text {h }}$ əuva/ & /gidor/ & Infant or small child \\
\hline 3 & /leru/ & /batf'or/ & Calf \\
\hline 4 & $/ t^{h} \partial g r i /$ & /tthagol/ & Goat \\
\hline 5 & /məth ${ }^{\mathrm{h}} \mathrm{ri} /$ & $/$ matg $^{\text {h }} /$ & Fish \\
\hline 6 & /sã:r/ & /damra/ & Ox \\
\hline
\end{tabular}

Table 1. Cross comparison of [ $\mathrm{k}^{\mathrm{h}}$ aspəilija] variety of Khortha spoken in Jharkhand (Khortha-1) and in the bordering region of West Bengal (Khortha-2)

\footnotetext{
${ }^{3}$ Chhatank is a liquid measuring device from the ancient Indian weights and measuring system where 4 Chhatank is equal to $250 \mathrm{gms}$.
} 
On the other hand, the [golvari] variety of Khortha is also carried out on the basis of the same measuring device. This device is believed to carry 18 chhatank grains which is equal to $1.125 \mathrm{gm}$ of grains. Speakers of this variety of Khortha are spread in the areas such as the Kasmar block of Bokaro district to the Bheda [ $b^{\text {h }} e$ ra] river. The Bheda river merges with the Damodar River near the famous Rajrappa shrine in Ramgarh district. Since this variety of Khortha is in direct contact with Kurmali (an Indo-Aryan language spoken in and around the districts of Ramgarh, Hazaribagh, and so on) language, a lot of borrowings from Kurmali can be seen in [golvari]- viz. /aahe/ in place of /həi/ "is (aux pre-verb)" and /kər-is aahe/ in place of /kər-he/ "to (infinitive)". The WH marker /kina/ is used instead of /ki/ 'what'. It is quite interesting to note that since the ancient times, it has been the practice that the grains are always sold in the [sik ${ }^{\text {h}}$ rija] conversion rate; however, the same grains would always be purchased in the [golvari] conversion rate by the traders.

Apart from the above-mentioned varieties, Ohdar (2012) also noted that probably there exists a third variety too. This variety can be demarcated by the areal distribution of the areas which lie within the Ramgarh district. Ohdar also mentions that this variety has not been enlisted by any of the earlier researchers with any particular name; however, there is a common practice among the local people to refer to this variety of Khortha as [ramgər ${ }^{\mathrm{h}} \mathrm{ija}$ ]. This variety constitutes the properties of Kurmali and Nagpuri. For example, the Wh-property /ki/ 'what' as in /ki kərb'î/ 'what to be done' is said as /kina kərb'̂/. Once we proceeded towards the south of Ramgarh area, we observed the properties of Nagpuri. Consider the following examples in Table 2.

\begin{tabular}{|r|c|c|c|}
\hline \multicolumn{1}{|c|}{ Sl. no } & Khortha & /ramgər' ${ }^{\text {hija/ Khortha }}$ & Gloss \\
\hline 1. & $/$ kər həi/ & /kəreila/ & Worked \\
\hline 2. & $/ t^{\text {h}} \partial g \partial r i j ə n /$ & $/ t^{\text {h}}$ əgrimən/ & 'Goats' \\
\hline
\end{tabular}

Table 2. Example of the /ramgər ${ }^{h_{i j}}$ / Khortha variety

The other variety named as [desuali] is believed to be spoken in the Patratu district upto the West Palamu region in Jharkhand. This variety consists of properties of Magahi and Bhojpuri (Ohdar 2012). However, he did not cite any examples to support his claim. 
The fifth variety named as [pərnədija] is found to be spoken at the northern bank of Damodar River of Ramgarh. The interesting thing to notice here is that the distance between the two parts of the Damodar River is very less, but the differences in language can be noted down from the way this language is used by the native speakers of Khortha. Ohdar (2012) claimed that the [pərnədija] variety adds /+o/ suffix to the verb phrase and /+a/ suffix in the noun phrase (Table 3 ).

\begin{tabular}{|c|c|c|c|}
\hline Sl. no. & Khortha & /pərnədija/ Khortha & Gloss \\
\hline 1. & /kərhəi/ & /kəro+həi/ & 'doing' \\
\hline 2. & /b hat $k^{h}$ əile/ & $/ b^{h} a t a+a k^{h}{ }^{2} i l e /$ & 'You have eaten rice' \\
\hline 3. & /pet phaitgeləi/ & /peta+phaitgeləi/ & 'Stomach has bursted' \\
\hline
\end{tabular}

Table 3. Cross-comparison of /pərnədija/ Khortha variety

Ohdar (2012) also noted the sixth variety of Khortha as [sant ${ }^{\text {hal }}$ pərgənija]; which is spoken at the North Eastern region of Jharkhand and lies in the district of Santhal Pargana. It has been noted that the properties of Maithili are found integrated within the Khortha varieties spoken in this region. Interestingly, the 'be' verb 'is' has at least three representations: $/ \mathrm{t}^{\mathrm{h}} \mathrm{i} /, / \mathrm{t}^{\mathrm{h}} \mathrm{ik} /$ and $/ \mathrm{t}^{\mathrm{h}} \varepsilon /$. In accordance with this phenomenon, it was named as " $t$ hika-thiki Maithili" by Grierson in 1928 (as cited by Ohdar 2012). Ohdar (2012) argued that this property cannot be linked to the properties of Maithili, because the auxiliary verb in Maithili is used as $/ \mathrm{t}^{\mathrm{h}} \mathrm{ik} / \mathrm{but}$ the ' $\mathrm{t}{ }^{\mathrm{h}}$ ika- $\mathrm{t}^{\mathrm{h}}$ iki' property is very much close to /hik/ of Khortha. The property of epenthesis can also be noticed in other varieties of Khortha except the Santhal Parganiya variety (Table 4).

\begin{tabular}{|c|c|c|}
\hline SI. no. & Khortha varieties & Santhal Parganiya Khortha \\
\hline 1. & /ham kəirdeləi/ 'I have done' & /ham kərideləi/ 'I have done' \\
\hline 2. & /u təilgeləi/ 'He/She has left' & /u təligeləi/ 'He/She has left' \\
\hline
\end{tabular}

Table 4. Cross comparison of Khortha varieties 
On the basis of the above distinction of Khortha, we have sorted out the names of the regions according to the speech varieties mentioned by Ohdar (2012) and Jha (cited in Ohdar). Following Ohdar (2012), it can be said that there are six varieties of Khortha, spoken across the state of Jharkhand. The geographical distribution and the contact situations further contributed to bringing a few phonological and morphological changes across these varieties.

\begin{tabular}{|c|c|c|}
\hline Sl. no. & Types of Khortha & Spoken Areas \\
\hline 1. & $\begin{array}{l}\text { Deshwali } \\
\text { [dejuali] }\end{array}$ & $\begin{array}{l}\text { Places within the Patratu border to the Western side of } \\
\text { Palamu as in Daltanganj, Lohardaga etc. }\end{array}$ \\
\hline 2. & $\begin{array}{l}\text { Ramgharia } \\
\text { [ramgər }{ }^{h_{i j}} \text { ]a] }\end{array}$ & Ramgarh, Hazaribagh, Bhurkunda, Eastern Patratu, etc. \\
\hline 3. & $\begin{array}{l}\text { Parnadiya } \\
\text { [pərnədija] }\end{array}$ & $\begin{array}{l}\text { The northern side of Damodar River in and around Nai Sarai } \\
\text { River situated opposite to Ramgarh }\end{array}$ \\
\hline 4. & $\begin{array}{l}\text { Sikhariya } \\
\text { [sik }{ }^{\text {h}} \text { rijia] }\end{array}$ & $\begin{array}{l}\text { Jainamore, Parasnath Pahad, Topchanchi, Giridih up-to } \\
\text { Eastern Bengal borders. }\end{array}$ \\
\hline 5. & $\begin{array}{l}\text { Santhal Parganiya } \\
\text { [sant }{ }^{\text {h}} \text { al pərgənija] }\end{array}$ & $\begin{array}{l}\text { Deoghar, Madhupur, Dumka, and other Northeastern areas } \\
\text { of Jharkhand. }\end{array}$ \\
\hline 6. & $\begin{array}{l}\text { Golwari } \\
\text { [golvari] }\end{array}$ & $\begin{array}{l}\text { South of Ramgarh area from Kasmar, Kherachatta, Gola, } \\
\text { Rajrappa, etc. }\end{array}$ \\
\hline
\end{tabular}

Table 5. Types of Khortha varieties spoken in different geographical regions of Jharkhand

\section{Conclusion}

In the present work, a linguistic outline of Khortha has been discussed, considering the earlier literature of the language to its present social status. The present scope of the language used in the various domains of our day-to-day life has also been discussed. After examining the contemporary state of the language, the multiple speech varieties of Khortha were noted. This diversification automatically demands the necessity to comprehend, document and classify the entire language variety and conduct a cross-comparative study. 
Our main objective and focus is been to highlight the linguistic outline of Khortha and its varieties to the common mass in order to interpret the linguistic properties of the language so that the other major analyses can be done in the coming future by the language researchers.

\section{References}

DANGI, A.K. (2012) Khortha Bhasha: Ek Parichay (Khortha Language: An Identity), Jamshedpur, Jharkhand: Spardha Publications.

DASH, N.S. \& A. AMAN (2015) "Generation of a Dialect Corpus in Khortha used in Jharkhand India: Some Empirical Observations and Theoretical Postulations", Journal of Advanced Linguistic Studies, 4, 1-2, 151-171.

DAS, P.K (2013) "Ergativity in Khortha: an enigmatic phenomenon", The Journal of South Asian Studies, HUFS, South Korea, 18, 3, 1.

GRIERSON, G. A (1927) Linguistic survey of India, 1927: Introduction, Central Publication Branch, Calcutta: Government of India.

OHDAR, B. (2012) Khortha Bhasha Evam Sahitya: Udbhav Evam Vikash (Khortha Language and Literature: Origin and Growth), Ramgarh: Khortha Bhasha Sahitya Academy.

PRASAD, B.N. \& S. SHASTRI (1958) Linguistic Survey of the Sadar Subdivision of Manbhum and Dalbhum (Singhbhum), Patna: Bihar Rastrabhasha Parishad.

\section{Web references}

CENSUS (2001) Office of the Registrar General \& Census Commissioner, India <http://censusindia.gov.in/Census_Data_2001/Census_Data_Online/Language/Statement1 . aspx>

Census (2011) Office of the Registrar General \& Census Commissioner, India <www.censusindia.gov.in/2011Census/Language-2011/Statement-1.pdf>

THE TelegraPH, India (2011) published on $20^{\text {th }}$ August, Ranchi <https://www.telegraphindia.com/1110820/jsp/jharkhand/story_14400334.jsp> 